\title{
SURVEI 2009: MUTU SITUS E-LEARNING SEKOLAH INDONESIA MASIH SANGAT MINIM
}

\section{Heru Suhartanto}

Fakultas Ilmu Komputer, Universitas Indonesia, Kampus Baru UI Depok, Jawa Barat, 16424, Indonesia

\author{
E-mail: heru@cs.ui.ac.id
}

\begin{abstract}
Abstrak
Di beberapa negara yang infrastruktur internet telah memadai, banyak sekolah yang telah memanfaatkannya sebagai salah satu faktor pendukung kesuksesan proses pembelajaran. Pemerintah Indonesia pun telah memulai teknologi ini guna memperluas akses sumber daya pembelajaran sehingga tak terbatas oleh waktu dan ruang. Makalah ini melaporkan hasil survei yang menggambarkan seberapa jauh sistem e-learning telah dipakai di sekolah Indonesia. Data hasil survei menunjukkan bahwa kualitas pemanfaatan situs e-learning masih kurang dan perlu mendapat perhatian dan dukungan dari semua pihak terkait.
\end{abstract}

Kata Kunci: internet, e-learning

\section{Abstract}

In some countries that have adequate internet infrastructure, many schools are already using it as one of the factors supporting the success of the learning process. The Indonesian government also has initiated this technology to expand the access to learning resources that is unlimited by time and space. This paper reports the results of the survey that describe the extent to which e-learning system has been used in Indonesian schools. Survey data indicate that the quality of utilization of e-learning is still lacking and need attention and support from all parties concerned.

Keywords: internet, e-learning

\section{Pendahuluan}

Di suatu negara dengan infrastruktur internet memadai, e-learning sangat dimanfaatkan oleh kebanyakan institusi pendidikan guna mendukung proses pembelajaran. Banyak yang berpendapat bahwa e-learning tidak dimaksudkan untuk mengganti seluruh proses pembelajaran, namun dapat mengganti sebagian atau mendukung. Terutama kemampuan sistem tersebut untuk menyediakan akses proses pembelajaran tanpa terkendala waktu dan tempat. Sementara [1] melaporkan hasil studi bahwa studi online dapat lebih baik dari studi model tradisional. [2] melaporkan bahwa studi awal dampak e-learning mampu meningkatkan kemampuan siswa terutama siswa dari sekolah yang kurang mampu.

Pemerintah Indonesia pun berusaha meningkatkan infrastruktur internet di sekolah sekolah untuk mewujudkan akses sumber pembelajaran yang tak terbatas. [3] melaporkan bahwa Susilo Bambang Yudhoyono berjanji internet masuk desa pada tahun 2010. [4] melaporkan bahwa Direktorat Jenderal Manajemen Pendidikan Dasar dan Menengah (Ditjen Mandikdasmen) Departemen Pendidikan Nasional (Depdiknas) menerapkan proses belajar mengajar berbasis teknologi informasi dan komunikasi (TIK) kepada siswa SMP Terbuka mulai tahun 2009. [5] melaporkan bahwa penyediaan internet secara massal $(17,500$ sambungan) merupakan urutan pertama program 100 hari Mendiknas. [6] melaporkan bahwa sudah 18000 sambungan internet tercapai pada 27 Desember 2009.

Paper ini melaporkan hasil riset dari survei tentang keadaan terkini status pemanfaatan internet dalam penyediaan situs pembelajaran sekolah Indonesia.

\section{Metodologi}

Survei dilakukan dengan mencari situs melalui media Google selama bulan November 2009. Kata kunci yang dipakai adalah kombinasi kata-kata e-learning, online, sekolah, SMA, SMU, SMP, SMK, SD. Pendekatan ini didasarkan bahwa situs pembelajaran harus dapat dicari dan diakses via internet yang merupakan syarat utama e-learning. Kemudian sewaktu situs ditemukan, isinya diamati dan dilakukan pengkategorian yaitu kategori tingkat sekolah, satu untuk tingkat SMA, dua untuk tingkat SMP, dan tiga untuk tingkat SD. Kategori kualitas situs, yakni kategori A jika 
suatu sekolah telah mempunyai situs berbasis Learning Management System (misalnya Moodle) dan situs tersebut mempunyai lebih dari sepuluh mata pelajaran yang dipraktekkan. Kategori B jika situs sudah berbasis LMS namun kurang dari sepuluh mata pelajaran yang dipraktekkan. Kategori C jika suatu sekolah mempraktekkan e-learning dengan posting dan diskusi dalam bentuk situs Blog, serta jumlah mata pelajaran yang telah dipraktekkan lebih dari sepuluh. Kategori D, seperti C namun kurang dari sepuluh mata pelajaran. Kategori E, jika $e$ learning hanya difasiltitasi dalam bentuk arsip mata pelajaran dalam suatu situs, namun tanpa ada forum diskusi. Kategori F, jika isi situs tak bisa diamati karena beberapa sebab antara lain error, defacing, dan sejenisnya.

Kemudian untuk setiap kategori tersebut perlu dibedakan atau diberi label mana yang dalam dua tahun terakhir materinya direvisi dan mana yang tidak. Berdasarkan metodologi tersebut hasil dari survei dibuatkan dalam bentuk table yang memuat nama sekolah, lokasi sekolah, provinsi sekolah, situs sekolah, situs e-learning sekolah, kategori e-learning, dan kategori revisi $e$ learning. Berdasarkan tabel ini kemudian dilakukan analisis.

\section{Hasil dan Pembahasan}

Data yang diperoleh penulis dapat diakses di [7]. Dari data tersebut, total jumlah sekolah yang memiliki situs pembelajaran adalah 187 sekolah yang tersebar dalam 20 provinsi, satu luar negeri dengan dominasi terdapat di Pulau Jawa. Situs dari luar negeri adalah milik sekolah Indonesia di Cairo, Mesir. Lima provinsi urutan teratas adalah Jawa Tengah, Jawa Barat, DI Yogyakarta, Jawa Timur, dan DKI berturut turut masing masing 41, 33, 30, 27 dan 16 situs. Rincian sebaran data ini terlihat pada tabel I. Jika dikaitkan dengan urutan utama target 100 hari Mendiknas yang mencatumkan koneksi internet di sekolah sebanyak 17.500 sambungan maka tingkat keberhasilan koneksi internet dalam mendukung proses pembelajaran di sekolah adalah masih sangat kurang yakni hanya sekitar 1 $\%$.

Lalu, menurut [8] jumlah sekolah di seluruh Indonesia dari tingkat SD sampai SMA termasuk SMK yang telah mempunyai nomor pokok sekolah nasional adalah 289.171, sedangkan DKI adalah 6.299 sekolah dengan non SD adalah 2.546 sekolah. Jika dilihat prosentase secara nasional maka tingkat capaian kurang dari satu per mil. Hal ini masih dapat dimaklumi mengingat jumlah sekolah yang mempunyai infrastruktur listrik dan internet secara nasional masih sangat minim. Namun yang kurang menggembirakan adalah mutu situs pembelajaran sekolah di DKI yakni hanya sekitar enam per mil. Hal ini berasal dari 16 sekolah yang mempunyai situs pembelajaran dibandingkan 2.546 jumlah sekolah non SD.

TABEL I

SEbaran Situs Pembelajaran Per PRovinsi

\begin{tabular}{|c|c|c|c|c|c|c|}
\hline \multirow{2}{*}{ PROVINSI } & \multicolumn{6}{|c|}{ KATEGORI } \\
\hline & $\mathrm{A}$ & $\mathrm{B}$ & $\mathrm{D}$ & $E$ & $\mathrm{~F}$ & Total \\
\hline Bali & 1 & 2 & & & & 3 \\
\hline Banten & 1 & 3 & & 1 & & 5 \\
\hline DI Yogyakarta & 16 & 11 & & 2 & 1 & 30 \\
\hline DKI Jakarta & 1 & 12 & & 3 & & 16 \\
\hline Jawa Barat & 12 & 20 & & & 1 & 33 \\
\hline Jawa Tengah & 16 & 18 & 2 & 3 & 2 & 41 \\
\hline Jawa Timur & 7 & 16 & & 2 & 2 & 27 \\
\hline Kalimantan Barat & 1 & 3 & & & & 4 \\
\hline Kalimantan Selatan & & 2 & & & & 2 \\
\hline Kalimantan tengah & & 1 & & & & 1 \\
\hline Kalimantan Timur & 1 & 2 & & & & 3 \\
\hline $\begin{array}{l}\text { Kepulauan } \quad \text { Bangka } \\
\text { Belitung }\end{array}$ & & 1 & & & & 1 \\
\hline Kepulauan Riau & & 1 & & & & 1 \\
\hline Lampung & & 1 & & & & 1 \\
\hline Riau & 1 & & & & & 1 \\
\hline Sulawesi Selatan & 1 & 4 & & & & 5 \\
\hline Sulawesi Tengah & 3 & & & & & 3 \\
\hline Sumatera Barat & 1 & & & 2 & & 3 \\
\hline Sumatera Selatan & & 1 & & 1 & 1 & 3 \\
\hline Sumatera Utara & & & & 1 & & 1 \\
\hline Luar Negeri & 3 & & & & & 3 \\
\hline Grand Total & 65 & 98 & 2 & 15 & 7 & 187 \\
\hline
\end{tabular}


Sesuai dengan tingkat kematangan siswa, maka mayoritas adalah tingkat SMA yang sudah memanfaatkan untuk pembelajaran, kemudian SMP dan terakhir SD, masing masing total adalah sebanyak 135,.41 dan 11 situs. Rincian hasilnya dapat dilihat pada tabel II.

TABEL II

SiTUS TINGKAT SEKOLAH

\begin{tabular}{lcccccc}
\hline \multicolumn{7}{c}{ KITUS TINGKAT SEKOLAH } \\
\hline \multicolumn{7}{c}{ Kategori } \\
\hline Tingkat & A & B & D & E & F & Total \\
\hline SD & 2 & 8 & & 1 & & 11 \\
SMA & 49 & 69 & 1 & 9 & 7 & 135 \\
& & & & & & \\
SMP & 14 & 21 & 1 & 5 & & 41 \\
Total & 65 & 98 & 2 & 15 & 7 & 187 \\
\hline \hline
\end{tabular}

Jika dilihat dari distribusi sekolah negeri dan swasta, sekolah negeri lebih banyak dibandingkan swasta, yakni berturut turut 134 dan 53 (tabel III).

TABEL III

SITUS DI SEKOLAH NEGERI DAN SWASTA

\begin{tabular}{lcccccc}
\hline \hline & \multicolumn{7}{c}{ Kategori } \\
& A & B & D & E & F & Total \\
\hline Negeri & & & & & & \\
\hline Negeri & 38 & 76 & 2 & 12 & 6 & 134 \\
& & & & & & \\
Swasta & 27 & 22 & & 3 & 1 & 53 \\
& & & & & & \\
Total & 65 & 98 & 2 & 15 & 7 & 187 \\
\hline \hline
\end{tabular}

Secara umum, kualitas situs secara kuantitas masih sangat minim. Jika ditelusuri lebih jauh kualitas isi situs tersebut, maka banyak yang tak terpelihara dengan baik. Bahkan beberapa situs mengalami error dan tak menghubungkan dengan situs bermateri pembelajaran. Kebanyakan situs yang mengalami error adalah yang di-hosting sendiri di suatu tempat. Sedangkan situs yang relatif lebih baik adalah situs beberapa sekolah yang bekerja sama dengan institusi yang sudah mapan dalam pengelolaan situs e-learning, seperti http://www3.jogjabelajar.org/ dimanfatkan oleh beberapa sekolah di Yogyakarta, http://esfindo.cs.ui.ac.id yang secara gratis sudah dimanfaatkan oleh beberapa sekolah di Jabodetabek dan Tasikmalaya, dan http://elcom.umy.ac.id/elschool/ yang dipakai oleh beberapa sekolah di Yogyakarta.

Kemudian jika dilihat dari segi keteraksesan isi, maka mayoritas menerapkan akses terbatas yakni, hanya anggota pengikut pelajaran tersebut yang dapat mengakses materi secara penuh. Prinsip berbagi dengan sekolah lain belum menjadi budaya. Namun beberapa situs di bawah [9] telah membuka diri untuk dapat diakses oleh pihak lain.

\section{Kesimpulan}

Ada beberapa faktor yang menyebabkan kualitas situs tersebut kurang memadai, yaitu Secara nasional, infrastruktur dasar keperluan pembelajaran di sekolah masih minim terutama apabila dikaitkan dengan kebutuhan internet. Selain itu, beberapa sekolah belum mengganggap e-learning sebagai salah satu faktor pendukung pembelajaran. Kesimpulan ini penulis peroleh dari hasil kegiatan Workshop dan Pelatihan Esfindo 23-24 Oktober 2009. Hanya 41 dari 133 sekolah undangan yang hadir diwakili oleh 80 guru dari 399 undangan.

Faktor lainnya dikarenakan sekolah mempunyai beberapa target yang lebih penting dibandingkan dengan pemberdayaan e-learning. Salah satu targetnya adalah kesuksean dalam ujian akhir nasional. Pada sekolah yang cukup peduli atau berminat dengan e-learning, terjadi salah persepsi tentang peran guru Teknologi Informasi dan Komunikasi (TIK). Hasil wawancara dengan guru-guru peserta workshop dan training menjelaskan adanya beban yang terlalu berat dipundak mereka yang diharapkan oleh sekolah. Di sini perlu pemahaman adanya standar pengelolaan TIK di tingkat sekolah yang harus ada mengelola fasilitas TIK dan Sistem Informasi termasuk e-learning terpisah dari guru TIK.

Belum adanya standar minimum implementasi e-learning yang resmi dari pemerintah, namun beberapa strategi telah diusulkan di [10] menjadi faktor penghambat lainnya juga. Strategi ini melibatkan semua pemangku kepentingan.

\section{Acknowledgement}

Penulis mengucapkan terima kasih kepada Ikhlas Purwanto, lulusan Program S1 Fasilkom UI yang telah membantu pengumpulan data serta para anggota Tim LitBang Esfindo yang telah 
memberikan masukan penyempurnaan makalah ini.

\section{Referensi}

[1] S. Lohr, Study Finds that Online Education Beats the Classroom, http://ref-notes.blogspot.com/2009/08/studyfinds-that-online-education-beats_19.html, 2009, retrieved January 15, 2010.

[2] H. Suhartanto, Pemanfaatan Portal Pembelajaran untuk Peningkatan Kualitas Pendidikan Anak Jalanan / Komunitas Miskin Kota, Laporan Hibah Penelitian PHKI C1 UI, Universitas Indonesia, Depok, 2008.

[3] W. Daniel, Pidato di DPD: SBY Janjikan Internet masuk Desa 2010, detikNet http://www.detikinet.com/read/2009/08/19/1 22240/1185561/398/sby-janjikan-internetmasuk-desa-2010, 2009, retrieved January $16,2010$.

[4] http://www.suarapembaruan.com/News/2009 /08/22/index.html, retrieved January 16, 2010.

[5] Latief, Inilah 8 Program 100 Hari Pertama Mendiknas!, Kompas, http://edukasi.kompas.com/read/xml/2009/11 /06/1636152/inilah.8.program.100.hari.perta ma.mendiknas, 2009, retrieved January 16, 2010.

[6] D. Sari, Pustekkom Ingatkan Pemanfaatan Internet di 18 ribu Sekolah, Tempo, http://www.tempointeraktif.com/hg/pendidik an/2009/12/27/brk,20091227-

215818,id.html, 2009, retrieved January 17, 2010.

[7] H. Suhartanto dan I. Purwanto, Data survei e-learning Indonesia,

http://telaga.cs.ui.ac.id/ heru/esfindo/survey $\%$ 20elearning\%20SD-SMP-SMA-

26des09.xls, 2009, retrieved February 14, 2010.

[8] Website Nomor Pokok Sekolah Nasional, PDSP-KEMDIKBUD Indonesia, http://npsn.diknas.go.id/, retrieved February $17,2010$.

[9] H. Suhartanto, E-School for Indonesia (Esfindo), http://esfindo.cs.ui.ac.id, retrieved February 20, 2010.

[10] H. Suhartanto, Strategi Implementasi Sistem E-learning untuk Peningkatan Mutu Pendidikan Sekolah Indonesia, 2009, unpublished. 